\title{
CLUSTER ANALYSIS IDENTIFIED RAINFALL HOMOGENEOUS REGIONS IN TOCANTINS STATE, BRAZIL
}

\author{
ANÁLISES DE AGRUPAMENTO IDENTIFICARAM REGIÕES \\ PLUVIOMETRICAMENTE HOMOGENNEAS NO ESTADO DE TOCANTIS, BRASIL
}

\section{José Francisco de OLIVEIRA-JÚNIOR'; Fábio Miranda Gomes XAVIER ${ }^{1}$; Paulo Eduardo TEODORO²; Givanildo de GOIS'; Rafael Coll DELGADO ${ }^{1}$}

1. Instituto de Florestas, Universidade Federal Rural do Rio de Janeiro - UFRRJ, Seropédica, RJ, Brasil; 2. Departamento de Agronomia, Universidade Federal de Mato Grosso do Sul - UFMS, Chapadão do Sul, MS, Brasil. eduteodoro@ hotmail.com

\begin{abstract}
Identifying homogeneous regions regarding the monthly rainfall is relevant in agricultural planning, especially in relation to the installation of crops. Thus, the aim of this study was to apply the cluster analysis using Ward's algorithm to identify homogeneous regions in Tocantins State. Rainfall database of 34 stations (sites) of Tocantins, from 1976 to 2012, it were obtained of the Database of the Agência Nacional de Águas, Instituto Nacional de Meteorologia and Serviço Meteorológico do Brasil. Thus, were formed 408 time series (12 months $\times 34$ sites $)$ wherein AA technique was applied in conjunction with Ward's algorithm. Three homogeneous regions in relation to monthly rainfall were identified. Group 1, located in the extreme north of the state, has intermediate average values (135.58 $\mathrm{mm})$ to the other groups. Group 2 showed the greatest variance $\left(13,543.68 \mathrm{~mm}^{2}\right)$ and higher average (162.19 mm) for the studied period. On the other hand, group 3 has the lowest average rainfall $(117.93 \mathrm{~mm})$ among the homogeneous groups. Separating the groups followed a north-south alignment which suggests that latitude is the physiographic factor that most influences the occurrence of monthly rainfall in the State of Tocantins.
\end{abstract}

KEYWORDS: Monthly rainfall. Spatial variability. Temporal variability. Ward's algorithm.

\section{INTRODUCTION}

The Midwest region of Brazil (Goiás, Mato Grosso, Mato Grosso do Sul and the Federal District) along with the Tocantins State have concentrated most of their economy on agriculture and livestock. In addition to this, the Midwest and the Tocantins State share the Araguaia-Tocantins watershed, responsible for the second largest in the country's energy production in the country (MARCUZZO et al., 2012). Besides the influence on agriculture and livestock, identifying homogeneous regions as well as the occurrence of rainfall is needed for the planning of water sources and reservoirs of hydroelectric plants, wich may bring problems to the urban water supply and electric power generation (RODRIGUES et al., 2013; CORRÊA et al., 2014; TEODORO et al., 2015a).

In an attempt to establish spatial patterns for the meteorological variables, the cluster analysis (CA) is the most used in literature on classification processes (JACKSON; WEINAND, 1995; CAÚLA et al., 2015). CA technique consists of determining the similarity or dissimilarity level between individuals through the application of a clustering function to a given variable and Ward's (1963) algorithm has been widely used in climatological studies with satisfactory results (MACEDO et al. 2010; OLIVEIRA et al. 2010). These techniques have been frequently employed, in Brazil. The determination of sites with similar behaviour was performed by Diniz et al. (2003), Keller Filho et al. (2005), Lyra et al. (2006), Martin et al. (2008), Lyra et al. (2014) and Teodoro et al. (2015b). These authors concluded that, once determined, these homogeneous regions, once determined, will provide subsidies for more detailed studies on climatic and agro climatic zonings for the State.

Nonetheless, the are no climatological studies concerning the Tocantins State, mainly in regarding characterization of rainfall regime and rainfall producers and inhibitors meteorological inhibitors systems. Therefore, the aim of this study was to apply the cluster analysis using Ward's algorithm to identify homogeneous regions in the Tocantins State.

\section{MATERIAL AND METHODS}

State of Tocantins (Figure 1) is located in northern Brazil, among the longitudes $44^{\circ} \mathrm{W}$ and $52^{\circ} \mathrm{W}$ and latitudes $14^{\circ} \mathrm{S}$ and $4^{\circ} \mathrm{S}$. It has an area of $277,720.520 \mathrm{~km}^{2}$, with 139 municipalities. Landscape is divided, in general, into plains and plateaus. The state is bathed by the basins of the Tocantins and Araguaia rivers. The climate is Aw, according to Köppen climate classification. Rainfall has an average annual of $1,200 \mathrm{~mm}$ and a maximum average of $1,700 \mathrm{~mm}$. Minimum annual average 
temperature is $23^{\circ} \mathrm{C}$, and the maximum average is $26^{\circ} \mathrm{C}$. Relative humidity ranges from a minimum annual average of $65 \%$, and average maximum of $75 \%$ (GOIS et al., 2015).

Rainfall database of 34 stations (sites) of Tocantins (Table 1), from 1976 to 2012, it were obtained of the Database of the Agência Nacional de Águas, Instituto Nacional de Meteorologia and Serviço Meteorológico do Brasil. Thus, were formed 408 time series (12 months x 34 sites). Processing of the data removing the outliers, which are observations that deviate markedly from the others in the sample in which they occur, causing inconsistencies was carried out. About $10 \%$ historical series showed failures (outliers), which are filled by the climatological normal of each of the 8 micro-regions of the State (Figure 1).

Table 1. Number of micro-region (N), micro-region, site, latitude $\left(^{\circ}\right)$ and longitude $\left(^{\circ}\right)$ of 34 sites in the Tocantins State, Brazil.

\begin{tabular}{|c|c|c|c|c|}
\hline $\mathrm{N}$ & Micro-region & Site & Latitude $\left({ }^{\circ}\right)$ & Longitude $\left({ }^{\circ}\right)$ \\
\hline \multirow{3}{*}{1} & Bico do Papagaio & Ananás & $-6,36$ & $-48,07$ \\
\hline & Bico do Papagaio & Araguatins & $-5,65$ & $-48,13$ \\
\hline & Bico do Papagaio & Tocantinopolis & $-6,29$ & $-47,39$ \\
\hline \multirow{6}{*}{2} & Araguaína & Araguanã & $-6,67$ & $-48,47$ \\
\hline & Araguaína & Arapoema & $-7,66$ & $-49,07$ \\
\hline & Araguaína & Colinas do Tocantins & $-8,05$ & $-48,48$ \\
\hline & Araguaína & Muricilândia & $-7,15$ & $-48,6$ \\
\hline & Araguaína & Wanderlândia & $-6,84$ & $-47,97$ \\
\hline & Araguaína & Xambioá & $-6,41$ & $-48,53$ \\
\hline \multirow{3}{*}{3} & Miracema do Tocantins & Abreulândia & $-9,62$ & $-49,16$ \\
\hline & Miracema do Tocantins & Bernardo Sayão & $-7,88$ & $-48,88$ \\
\hline & Miracema do Tocantins & Itaporã do Tocantins & $-8,57$ & $-48,69$ \\
\hline \multirow{3}{*}{4} & Porto Nacional & Palmas & $-10,31$ & $-48,16$ \\
\hline & Porto Nacional & Pedro Afonso & $-9,31$ & $-47,93$ \\
\hline & Porto Nacional & Porto Nacional & $-10,72$ & $-48,42$ \\
\hline \multirow{3}{*}{5} & Jalapão & Goiatins & $-7,71$ & $-47,32$ \\
\hline & Jalapão & Itacajá & $-8,39$ & $-47,76$ \\
\hline & Jalapão & Lizarda & $-9,59$ & $-46,68$ \\
\hline \multirow{4}{*}{6} & Rio Formoso & Araguaçu & $-12,93$ & $-49,83$ \\
\hline & Rio Formoso & Fátima & $-10,76$ & $-48,92$ \\
\hline & Rio Formoso & Dueré & $-11,34$ & $-49,27$ \\
\hline & Rio Formoso & Formoso do Araguaia & $-11,8$ & $-49,53$ \\
\hline \multirow{3}{*}{7} & Gurupi & Alvorada & $-12,49$ & $-49,12$ \\
\hline & Gurupi & Gurupi & $-11,74$ & $-49,14$ \\
\hline & Gurupi & Peixe & $-12,39$ & $-48,71$ \\
\hline \multirow{9}{*}{8} & Dianópolis & Almas & $-11,58$ & $-47,17$ \\
\hline & Dianópolis & Aurora do Tocantins & $-12,71$ & $-46,41$ \\
\hline & Dianópolis & Conceição do Tocantins & $-12,42$ & $-47,2$ \\
\hline & Dianópolis & Dianópolis & $-11,63$ & $-46,81$ \\
\hline & Dianópolis & São Valério da Natividade & $-11,53$ & $-48,29$ \\
\hline & Dianópolis & Natividade & $-11,7$ & $-47,73$ \\
\hline & Dianópolis & Pindorama do Tocantins & $-11,14$ & $-47,58$ \\
\hline & Dianópolis & Ponte Alta do Bom Jesus & $-12,09$ & $-46,48$ \\
\hline & Dianópolis & Porto Alegre do Tocantins & $-11,61$ & $-47,05$ \\
\hline
\end{tabular}




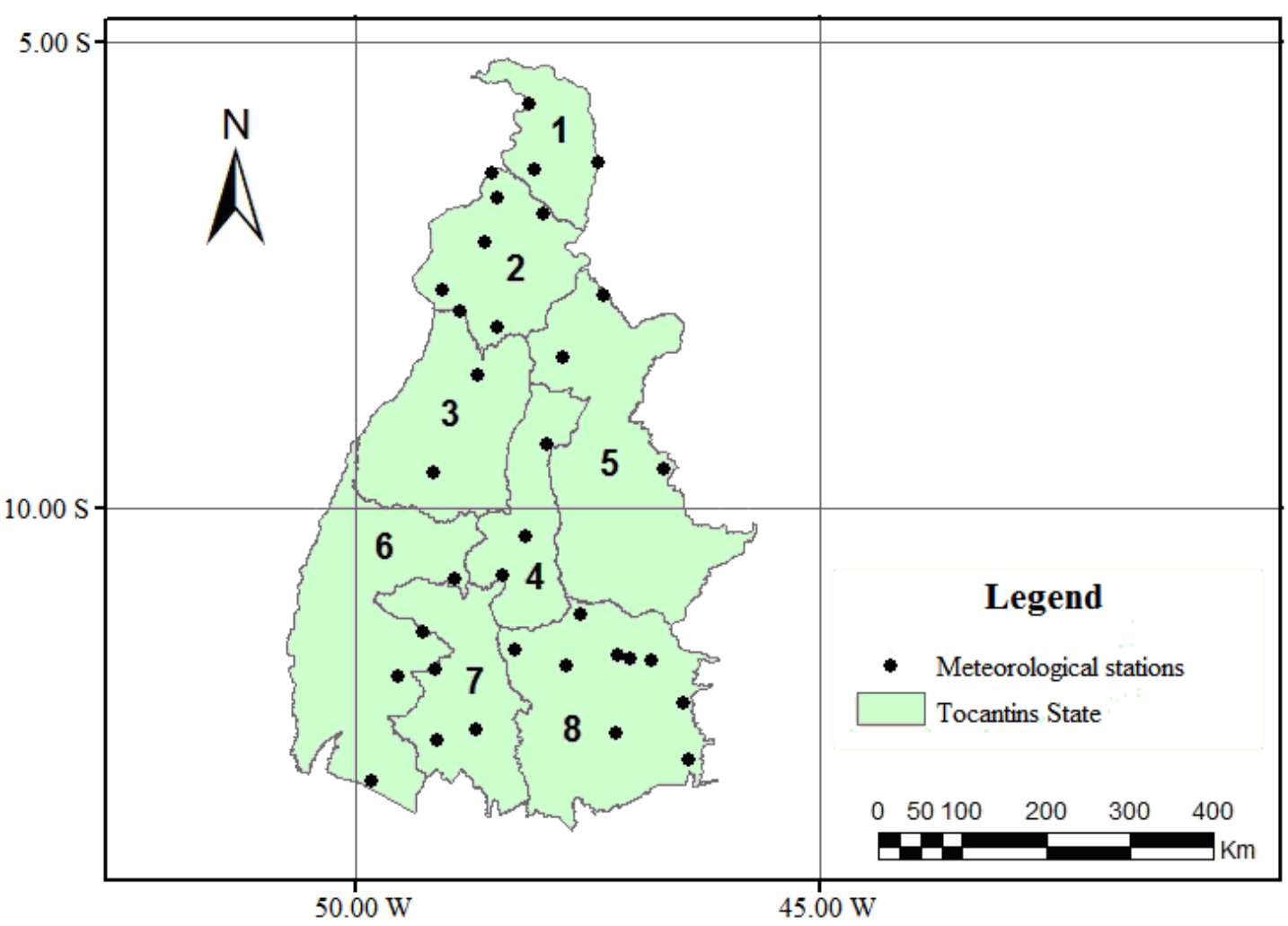

Figura 1. Distributions of meteorological stations (sites) and micro-regions of Tocantins State, Brazil.

For identifying the rainfall homogeneous regions, we applied the CA technique (Cluster). Average values of monthly rainfall were arranged in a matrix $P_{n \times p}$, where the element $P_{i j}$ representing the value of $i^{\text {th }}$ variable (site) of the $\mathrm{j}^{\text {th }}$ individual (month). Thus, each row vector represented a site and each column vector represented a month. It was used the Ward's agglomerative hierarchical algorithm (1963), using as dissimilarity measure the Euclidean distance (EVERITT; DUNN, 1991):

$d_{e}=\left[\sum_{j=1}^{n}\left(P_{p, j}-P_{k, j}\right)^{2}\right]^{\frac{1}{2}}$

where, $\mathrm{d}_{\mathrm{e}}$ is Euclidean distance; and $\mathrm{P}_{\mathrm{p}, \mathrm{j}}$ and $\mathrm{P}_{\mathrm{k}, \mathrm{j}}$ are quantitative variables $\mathrm{j}$ of individuals $\mathrm{p}$ and $\mathrm{k}$, respectively.

Ward's (1963) algorithm creates groups, minimizing the dissimilarity, or minimizing the total sums of squares within groups, also known as sum of square deviations (SSD). At each stage of the procedure, groups are formed in such a manner that the resultant solution has the lowest SSD within groups. At these stages, the joints of all possible pairs of groups are considered, and the two resulting in smaller increase SSD are clustered so that all groups form a single, gathering all individuals (EVERITT; DUNN, 1991).

\section{RESULTS AND DISCUSSION}

CA technique revealed three homogeneous groups as the monthly rainfall in the Tocantins State, Brazil (Figure 2). Group 1 was composed of municipalities Muricilândia, Ananãs, Araguanã, Araguatins, Xambioá, Tocantinópolis and Wanderlândia, which are concentrated in the north, with its nearby stations, or inserted in the Amazon portion of Tocantins State (Figure 3). The municipalities Pindorama do Tocantins, Goiatins, Itacajá, Itaporã do Tocatins, Arapoema, Colinas do Tocantins, Berardo Sayão, Ponte Alta do Bom Jesus, Pedro Afonso, Abreulândia, Fátima, Palmas, Porto Nacional and Duerê formed the Group 2, that is distributed over a larger area in length, and is positioned intermediate form to the Groups 1 and 3 . Group 3 was consisting by municipalities Alvorada, Araguaçu, Formoso do Araguaia, Peixe, Conceição do Tocantins, Gurupi, São Valério da Natividade, Aurora do Tocantins, Natividade, Dianápolis, Almas and Porto Alegre do Tocantins. This group occupies all its southern portion, with a station in central latitude of the Tocantins State, to the east. 


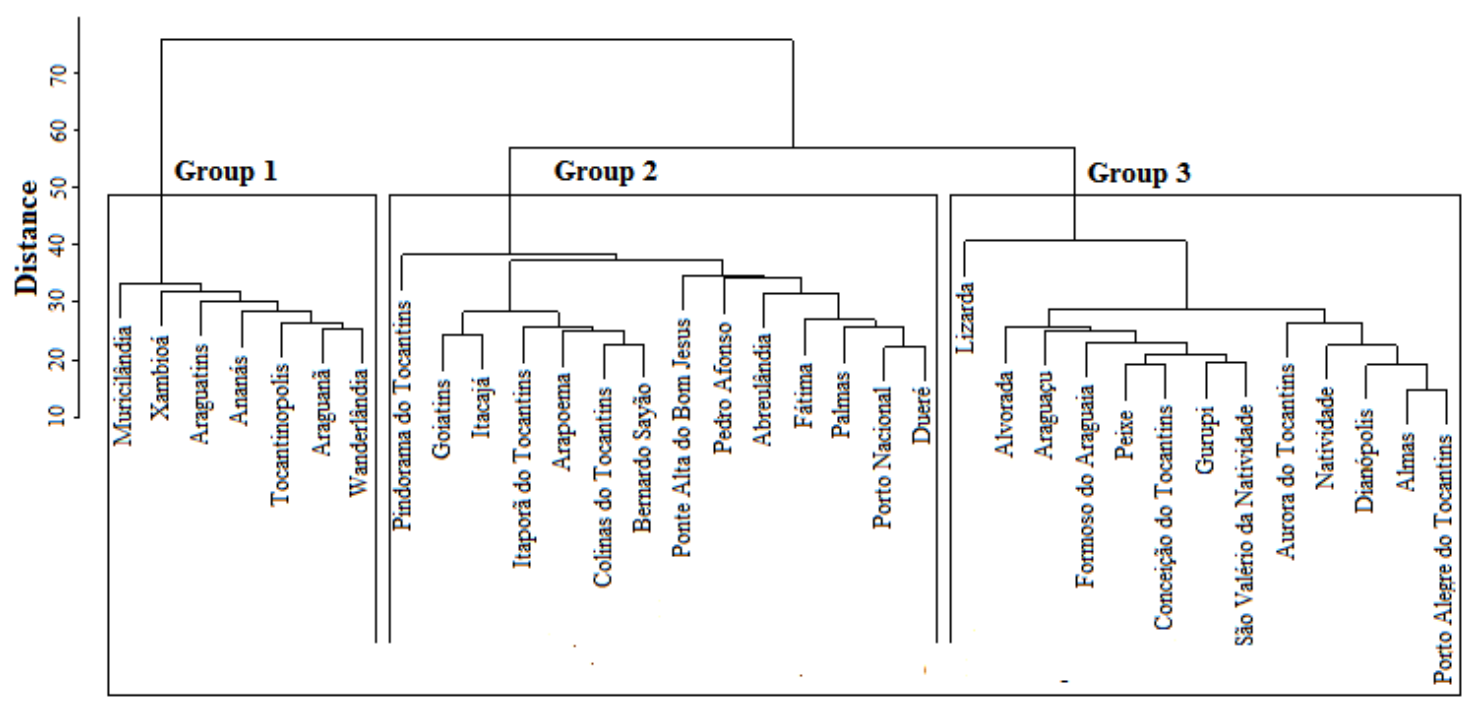

Figure 2. Cluster of homogeneous rainfall groups in Tocantis State, Brazil, based on the Euclidean mean distance and Ward's clustering method.

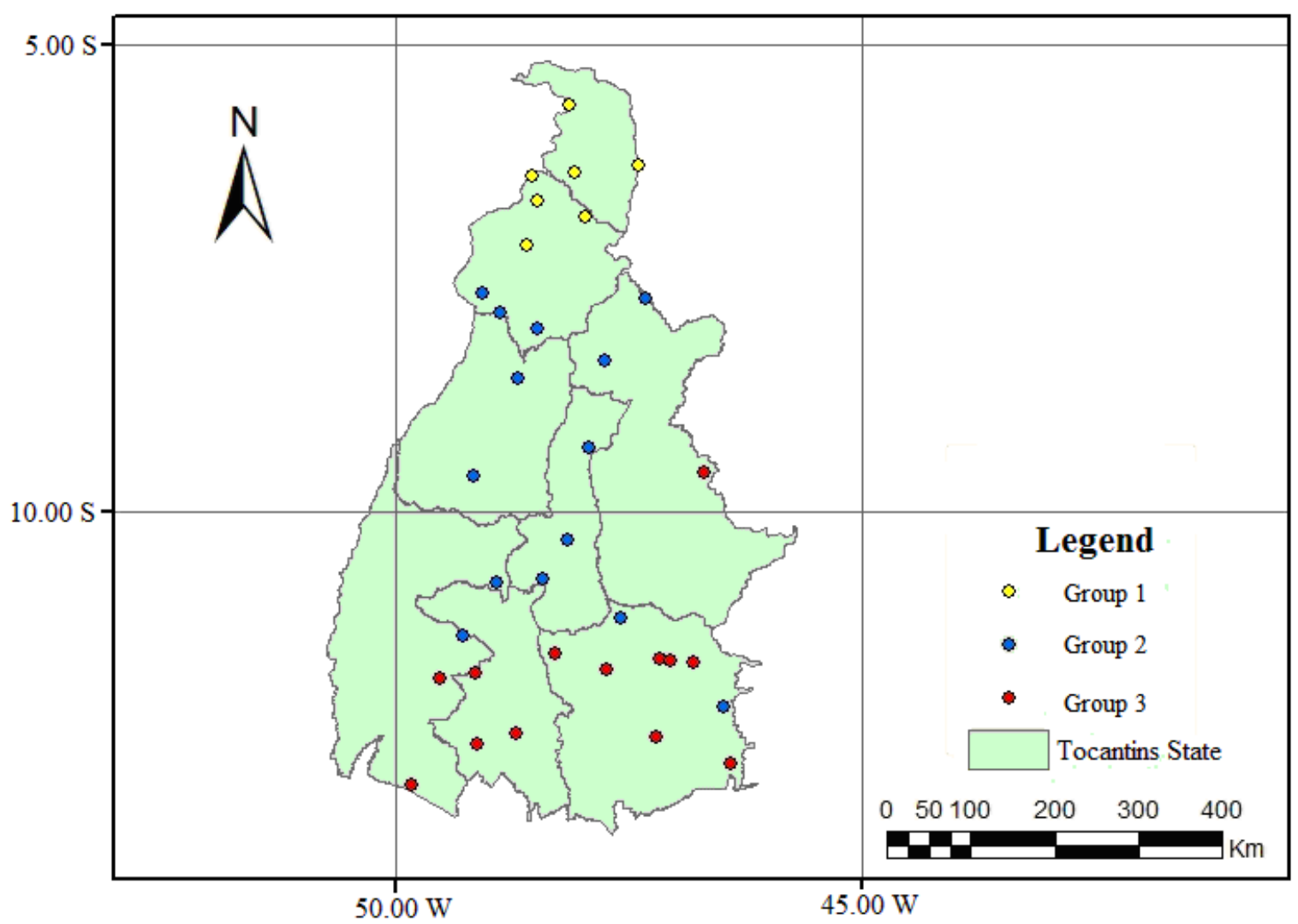

Figure 3. Location of homogeneous rainfall groups in Tocantis State, Brazil, based on the Euclidean mean distance and Ward's clustering method.

Group 1, located in the extreme north of the state, has intermediate average values $(135.58 \mathrm{~mm})$ when compared to the other groups. Its minimum monthly rainfall $(5.20 \mathrm{~mm}$, in July, in Tocantinópolis) is the highest, and its maximum (308.40 mm, in March, in Araguanã), lower than the extreme values of other groups. It is the group that has the lowest variance $\left(9,727.86 \mathrm{~mm}^{2}\right)$, i.e., the one that least oscillates the least in its rainfall, over the years, and its geographical distribution. This lower rainfall seasonality over the year is due to its proximity to the Amazon region. 
Table 2. Descriptive statistics of monthly rainfall for the homogeneous regions of the Tocantins State, Brazil, identified by cluster analysis.

\begin{tabular}{lccc}
\hline Statistic & Group 1 & Group 2 & Group 3 \\
\hline Minimum rainfall $(\mathrm{mm})$ & 5.20 & 0.86 & 0.11 \\
Month/Site of minimum & Julho/Tocantinópo & Julho/Palmas & Junho/Formoso do \\
rainfall & lis & 385.50 & Araguaia \\
Maximum rainfall $(\mathrm{mm})$ & 308.40 & Janeiro/Ponte Alta do Bom & Dezembro/Araguaçu \\
Month/Site of maximum & Março/Araguanã & Jesus & 117.93 \\
rainfall & 135.58 & 152.37 & 103.51 \\
Mean $(\mathrm{mm})$ & 125.00 & 162.19 & 103.93 \\
Median $(\mathrm{mm})$ & 98.63 & 116.38 & $10,800.43$ \\
Standard deviation $(\mathrm{mm})$ & $9,727.86$ & $13,543.68$ & \\
Variance $\left(\mathrm{mm}^{2}\right)$ & & & \\
\hline
\end{tabular}

Group 2 showed the lowest variance $\left(13,543.68 \mathrm{~mm}^{2}\right)$ for the studied period, ie greater oscillation between the monthly rainfall and the municipalities that compose it. This group also had the highest average $(162.19 \mathrm{~mm})$ probably due to the high humidity in the region covering the Rio Araguaia. On the other hand, group 3 has the lowest average rainfall $(117.93 \mathrm{~mm})$ among the homogeneous groups. The distance between the region covered by this group and the Amazon forest, and Rio river, causes this to be the driest region of the state, with climatic features similar to those of the states of Brazillian Midwest.
It can be verified by the box-plot analysis that group 1 has later rainy seasons (Figure 4), with low rainfall during the spring months. This infers a lower and later influence of the Continental Equatorial Mass $(\mathrm{mEc})$, and higher of the Intertropical Convergence Zone (ZCIT), on local rainfall. The ZCIT has intense activity in the summer, and extends to autumn, causing this group to have the highest monthly average from March to August, and present low monthly average low from September to December, compared with the other groups.

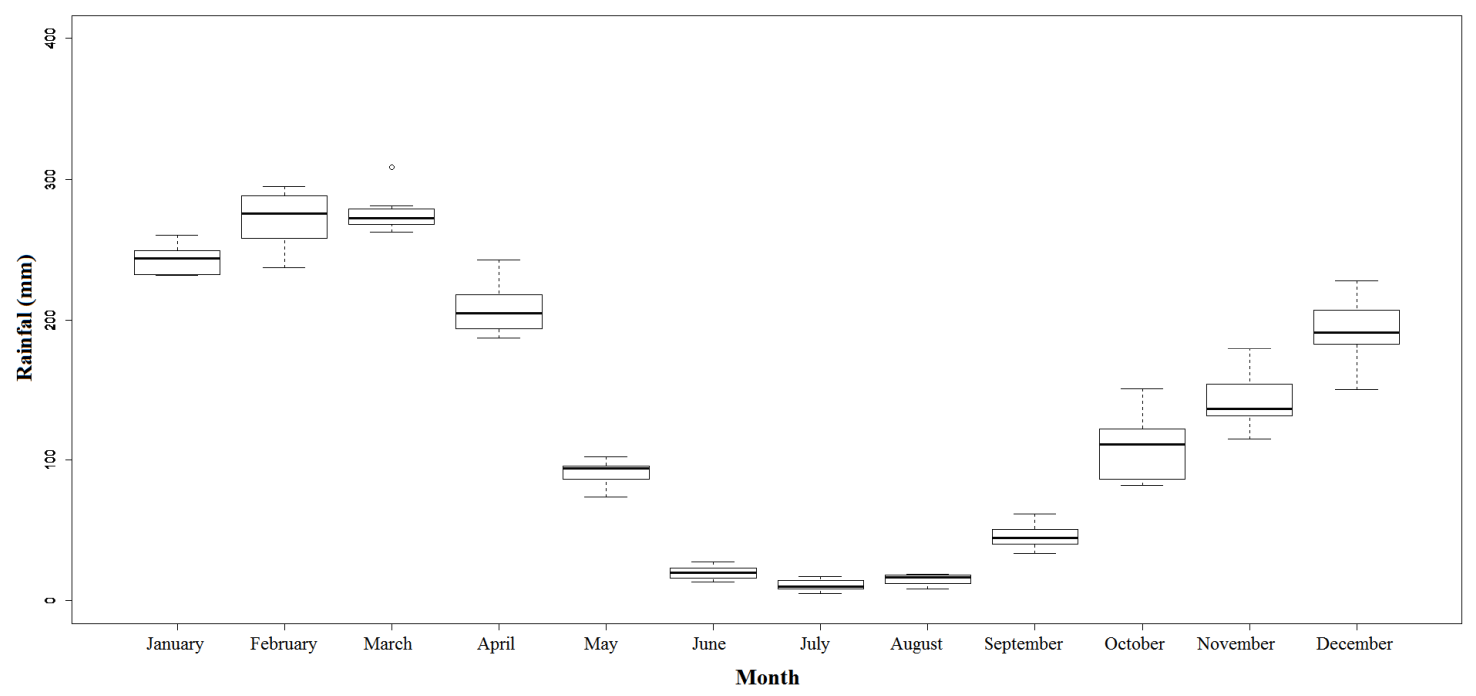

Figure 4. Box-plot of the average monthly rainfall (mm), considering the period 1976-2012, for Group 1.

The results generated by the box-plot analysis for Group 2 (Figure 5) confirmed that this has climatological features relating to rainfall, which are intermediate to others. In autumn and winter seasons, it is less dry than the Group 3, and less rainy than Group 1. Spring months shows a graph similar behavior to Group 3, but reaching higher averages. In the summer months, it features a graphic behavior similar to Group 1, but also with higher averages. 


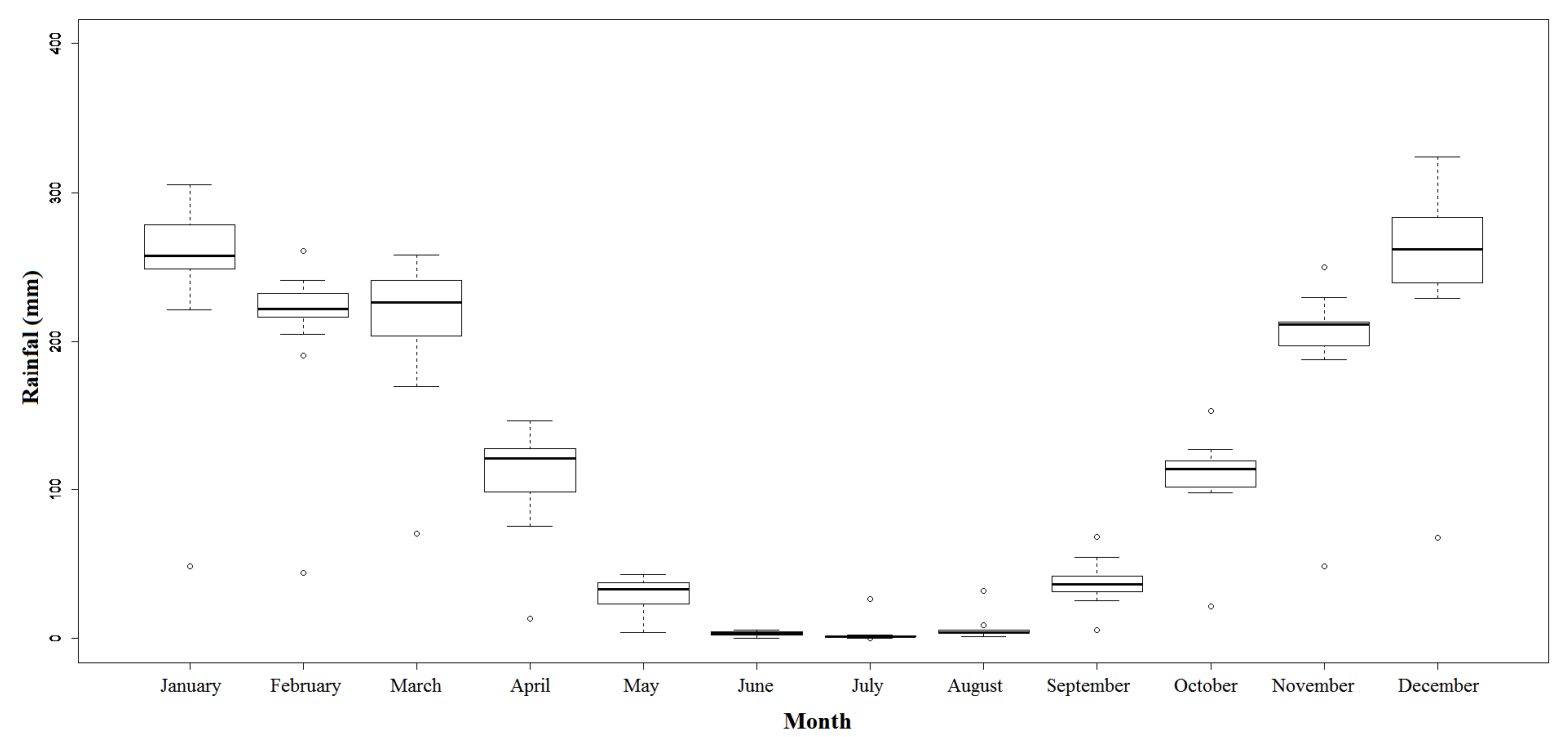

Figure 5. Box-plot of the average monthly rainfall (mm), considering the period 1976-2012, for Group 2.

The results of the box-plot analysis demonstrate that Group 3 (Figure 6) is more associated with the monsoon regime from the interior of the continent, and its rainfall patterns explained by the Equatorial Continental Mass $(\mathrm{mEc})$ action, which causes intense and frequent convective rainfall in the warmer months of the year. In the region of this group to the south, the presence of a low-pressure core occurs, which forces the flow and moisture transport through the valley of Tocantins, at low levels, and is coupled to anti-cyclonic circulation, at high levels, to the west region. The development of the anticyclone formed in the Bolivian altiplano region provides heat to the monsoon system in the region and it is intensified with the increase in convection during the months of highest temperature, usually, in December and January.

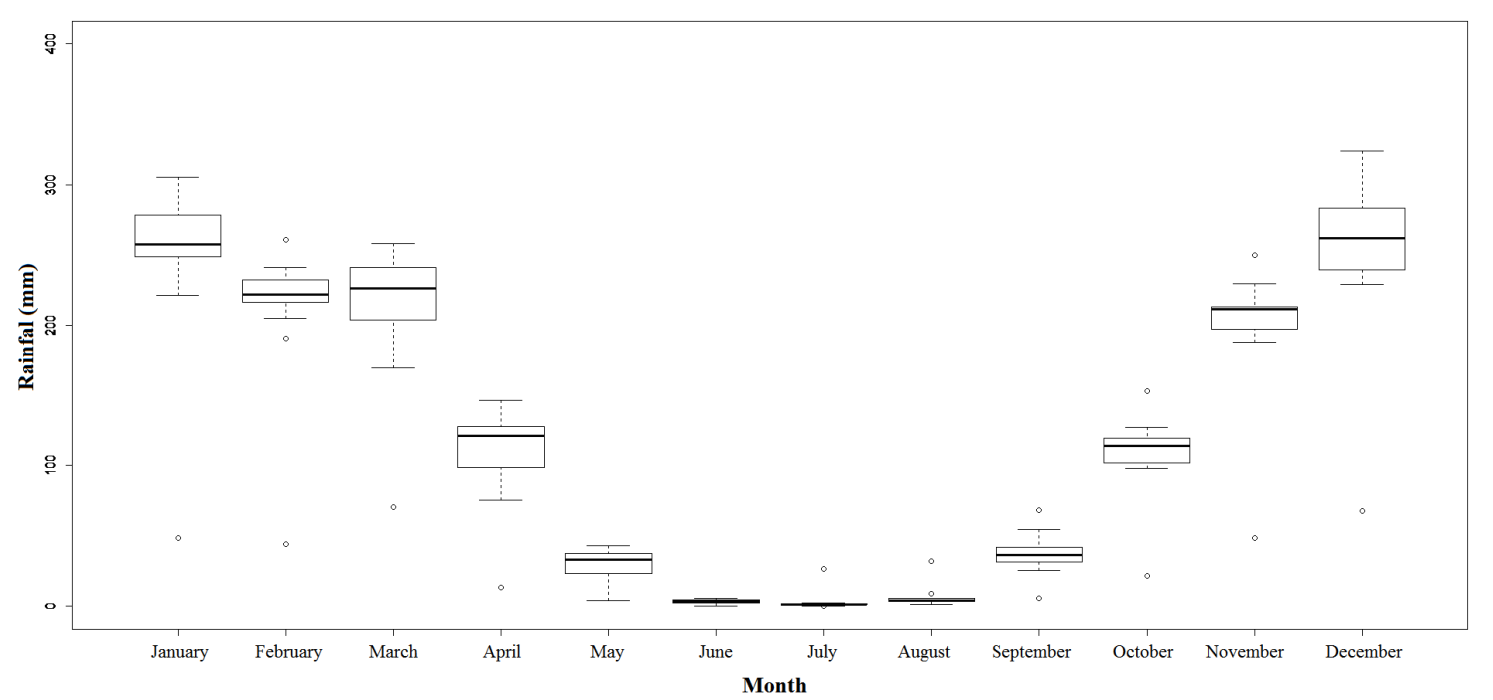

Figure 6. Box-plot of the average monthly rainfall (mm), considering the period 1976-2012, for Group 3.

Box-plot analysis (Figures 4, 5 and 6) allows for the assertion that the months from October to April are responsible for almost the entire annual rainfall in the State of Tocantins, corroborating the results obtained by Marcuzzo et al. (2012), that defines this period as rainy for the region. It is important to mention that the groups identified as homogeneous by AA followed a NorthSouth alignment. This behavior shows that despite the tropical features present in the Tocantins State, the latitude is, among the physiographic factors, the one that has the most influence in the monthly rainfall during the dry, transitional and rainy seasons, resembling the results obtained in studies performed in other Brazilian States (BAÚ et al. 2006, ÁVILA et al. 2009; ULIANA et al. 2013; TEODORO et al., 2015a,b). 


\section{CONCLUSIONS}

The cluster analysis in conjunction with the Ward algorithm identified three homogeneous regions in the state of Tocantins regarding monthly rainfall. Group 1, located in the extreme-north of the state, has intermediate mean values for the other groups. Group 2 presented the highest variance and
OLIVEIRA-JÚNIOR, J. F. et al.

highest mean for the study period. On the other hand, group 3 has the lowest rainfall among the homogeneous groups. The separation of the groups followed a North-South alignment, which suggests that the latitute is the physiographic factor that most influences the occurrence of monthly rainfall in the State of Tocantins.

RESUMO: A identificação de regiões homogêneas quanto a chuva mensal é relevante no planejamento agrícola, sobretudo no que diz respeito à instalação de culturas. Assim, o objetivo deste estudo foi aplicar a análise de agrupamento (AA) em conjunto com o algoritmo de Ward para identificar regiões homogêneas no Estado do Tocantins. Dados de precipitação mensal de 34 estações (locais) do Tocantins, de 1976 a 2012, foram obtidos do banco de dados da Agência Nacional de Águas, Instituto Nacional de Meteorologia e Serviço Meteorológico do Brasil. Assim, foram formadas 408 séries temporais (12 meses x 34 locais) em que foi aplicada a técnica AA em conjunto com o algoritmo de Ward. Foram identificadas três regiões homogenias quanto a precipitação mensal. O grupo 1, localizado no extremo-norte do estado, possui valores médios intermediários $(135.58 \mathrm{~mm})$ aos outros grupos. $\mathrm{O}$ grupo 2 apresentou a maior variância $\left(13,543.68 \mathrm{~mm}^{2}\right)$ e maior média $(162.19 \mathrm{~mm})$ para o período de estudo. Por outro lado, o grupo 3 possui a menor média pluviométrica $(117,93 \mathrm{~mm})$ dentre os grupos homogêneos. A separação dos grupos seguiu um alinhamento Norte-Sul, o que sugere que a latitute é o fator fisiográfico que mais influência na ocorrência da precipitação mensal no Estado do Tocantins.

Ward.

PALAVRAS-CHAVE: Precipitação mensal. Variabilidade espacial. Variabilidade temporal. Algoritmo de

\section{REFERENCES}

ÁVILA, L. F.; MELLO, C. R.; VIOLA, M. R. Mapeamento da precipitação mínima provável para o sul de Minas Gerais. Revista Brasileira de Engenharia Agrícola e Ambiental, Campina Grande, v. 13, p. 906-915, 2009.

BAÚ, A. L.; GOMES, B. M.; QUEIROZ, M. M. F.; OPAZO, M. A. U.; SAMPAIO, S. Comportamento espacial da precipitação pluvial mensal provável da mesorregião oeste do Estado do Paraná. Irriga, Botucatu, v. 11, p. 150-168, 2006.

CAÚLA, R. H. ; OLIVEIRA-JÚNIOR, J. F.; LYRA, G. B.; DELGADO, R. C. ; HEILBRON FILHO, P.F.L. Overview of fire foci causes and locations in Brazil based on meteorological satellite data from 1998 to 2011. Environmental Earth Sciences (Print), Melbourne, v. 74, p. 1497-1508, 2015.

CORREA, C. C. G.; TEODORO, P. E.; CUNHA, E. R.; OLIVEIRA-JÚNIOR, J. F.; GOIS G.; RIBEIRO, L.P.; BACANI, V. M.; TORRES, F. E. Spatial interpolation of annual rainfall in the State Mato Grosso do Sul (Brazil) using different transitive theoretical mathematical models. International Journal of Innovative Research in Science, Engineering and Technology, Tamilnadu, v. 3, n. 10, p. 16618-16625, 2014.

DINIZ, G.; BERLATO, M.A.; CLARKE, R.T.; FONTANA, D.C. Identificação de regiões homogêneas de temperaturas máxima e mínima do Rio Grande do Sul. Revista Brasileira de Agrometeorologia, Santa Maria, v. 11, n. 2, p. 303-312, 2003.

EVERITT, B. S.; DUNN, G. Applied multivariate analysis. London: Edward Arnold, 1991. 400p.

JACKSON, I. J.; WEINAND, H. Classification of tropical rainfall stations: A comparison of clustering techiques. International Journal of Climatology, London, v. 15, n. 9, p. 985-994, 1995. 
GOIS, G.; DELGADO, R. C.; OLIVEIRA-JÚNIOR, J. F. Modelos Teóricos Transitivos Aplicados na Interpolação Espacial do Standardized Rainfall Index (SPI) para os Episódios de El Niño Forte no Estado do Tocantins, Brasil. Irriga, Botucatu, v. 20, p. 371-387, 2015.

KELLER FILHO, T.; ASSAD, E. D.; LIMA, P. R. S. R. Regiões pluviometricamente homogêneas no Brasil. Pesquisa Agropecuária Brasileira, Brasília, v. 40, n. 3, p. 311-322, 2005.

LYRA, G. B.; GARCIA, B. I. L.; PIEDADE, S. M. S.; SEDIYAMA, G. C.; SENTELHAS, P. C. Regiões homogêneas e funções de distribuição de probabilidade da precipitação pluvial no Estado de Táchira, Venezuela. Pesquisa Agropecuária Brasileira, Brasília, v. 41, n. 2, p. 205-215, 2006.

LYRA, G. B.; OLIVEIRA-JÚNIOR, J. F.; ZERI, M. Cluster analysis applied to the spatial and temporal variability of monthly rainfall in Alagoas state, Northeast of Brazil. International Journal of Climatology, London, v. 34, p. 23452341, 2014.

MACEDO, M. J. H.; GUEDES, R. V. S.; SOUSA, F. A. S.; DANTAS, F. R. C. Análise do índice padronizado de precipitação para o estado da Paraíba, Brazil. Revista Ambiente \& Água, Taubaté, v. 5, n. 1, p. 204-214, 2010.

MARCUZZO, F. F. N.; OLIVEIRA, N. L.; PINTO FILHO, R. F.; FARIA, T. G. Chuvas na região centro-oeste e no Estado do Tocantins: análise histórica e tendência futura. Boletim de Geografia, Maringá, v. 30, n. 1, p. 19-30, 2012.

MARTIN, T. N.; STORCK, L.; DOURADO NETO, D. Simulação estocástica da radiação fotossinteticamente ativa e da temperatura do ar por diferentes métodos. Pesquisa Agropecuária Brasileira, Brasília, v. 42, n. 9, p. 1211-1219, 2007.

OLIVEIRA, L. F. C.; FIOREZE, A. P.; MEDEIROS, A. M. M.; SILVA, M. A. S. Comparação de Metodologias de Preenchimento de Falhas de Séries Históricas de Precipitação Pluvial Anual. Revista Brasileira de Engenharia Agrícola e Ambiental, Campina Grande, v. 14, n. 11, p. 1186-1192, 2010.

RODRIGUES, J. A.; SANTOS FILHO, J.; CHAVES, L. M. Funções densidade de probabilidade para a estimativa da precipitação mensal. Semina: Ciências Exatas e Tecnológicas, Londrina, v. 34, p. 03-08, 2013.

TEODORO, P. E.; CORREA, C. C. G.; TORRES, F. E.; OLIVEIRA-JÚNIOR, J. F.; SILVA JUNIOR, A. C.; GOIS, G.; DELGADO, R. C. Analysis of the Occurrence of Wet and Drought Periods Using Standardized Rainfall Index in Mato Grosso do Sul State, Brazil. Journal of Agronomy (Print), Nova York, v. 14, p. 80-86, 2015a. http://dx.doi.org/10.3923/ja.2015.80.86.

TEODORO, P. E.; OLIVEIRA-JÚNIOR, J. F.; CUNHA, E. R.; CORREA, C. C. G.; TORRES, F. E.; BACANI, V. M.; GOIS, G.; RIBEIRO, L. P. Cluster analysis applied to the spatial and temporal variability of monthly rainfall in Mato Grosso do Sul State, Brazil. Meteorology and Atmospheric Physics, Vienna, v. 126, p. 1-13, $2015 \mathrm{~b}$. http://dx.doi.org/10.1007/s00703-015-0408-y.

ULIANA, T. M.; REIS, E. F.; SILVA, J. G. F.; XAVIER, A. C. Precipitação mensal e anual provável para o Estado do Espírito Santo. Irriga, Botucatu, v. 18, p. 139-147, 2013.

WARD, J. H. Hierarchical grouping to optimize an objective function. Journal of the American Statistical Association, Washington, v. 58, n. 301, p. 236-244, 1963. 